\title{
CEMENT MATERIAL DEVELOPMENT USED FOR CEMENTING UNDERGROUND COAL GASIFICATION WELL
}

\author{
PENGEMBANGAN SEMEN UNTUK PENYEMENAN SUMUR \\ GASIFIKASI BATUBARA BAWAH TANAH
}

\author{
MIFTAHUL HUDA \\ R\&D Centre for Mineral and Coal Technology \\ Jalan Jenderal Sudirman 623 Bandung 40211 \\ Ph. (+6222) 6030483, Fax. (+6222) 6003373 \\ e-mail: miftahul.huda@esdm.go.id
}

\begin{abstract}
The R\&D Centre for Mineral and Coal Technology of the Ministry of Energy and Mineral Resources develops an underground coal gasification (UCG) technology including its UCG test in a coal mine at Musi Banyuasin regency, South Sumatra. The UCG is safer than the underground mine since there is no worker underground however there is a concern in risk of ground water pollution. One of the methods to reduce the risk is a proper installation of well casing and cementing that seal aquifer from contact with UCG product gas. Development of special cement for cementing UCG well is needed due to its high process temperature (up to $1300^{\circ} \mathrm{C}$ ). The objective of this research is to develop a cement material that can withstand high temperatures environment. Domestically available an oil well cement (OWC) and a castables (CT) were used for the experiments. Single material of OWC is not suitable for cementing UCG well since the OWC compressive strength reduced drastically at heat treatment above $300^{\circ} \mathrm{C}$ due to decomposition of portlandite and calcium silicate hydrate. On the other hand, there was a synergistic effect that resulted of higher compressive strength sample if $60 \%$ weight of OWC and $40 \%$ weight of CT was blended. The absence of portlandite and the presence of inert filler materials in the blend is believed to improve thermal and mechanical properties of the blend.
\end{abstract}

Keywords: underground coal gasification, oil well cement, castables, heat treatment

\begin{abstract}
ABSTRAK
Pusat Penelitian dan Pengembangan Mineral dan Batubara, Kementerian Energi dan Sumber Daya Mineral sedang mengembangkan teknologi gasifikasi batubara bawah tanah (underground coal gasification/UCG) dan telah melakukan uji coba UCG di sebuah tambang batu bara di Musi Banyuasin, Sumatera Selatan. UCG lebih aman dibandingkan tambang bawah tanah karena tidak ada pekerja yang berada di bawah tanah tetapi ada resiko polusi air tanah akibat kegiatan UCG. Pemasangan casing dan penyemenan sumur akan mengurangi resiko tersebut tetapi karena proses UCG melibatkan suhu hingga $1300^{\circ} \mathrm{C}$ maka pengembangan semen yang tahan suhu tinggi untuk penyemenan sumur UCG perlu dikembangkan. Tujuan penelitian ini adalah mengembangkan bahan semen tahan suhu tinggi. Semen sumur minyak (oil well cement/OWC) dan castables (CT) yang dapat diperoleh di dalam negeri digunakan sebagai bahan penelitian. Hasil penelitian menunjukkan OWC kurang sesuai untuk penyemenan sumur UCG karena kuat tekannya menurun secara drastis pada suhu di atas $300^{\circ} \mathrm{C}$. Hal ini terjadi karena awa-komposisi portlandit dan kalsium silikat hidrat pada suhu tersebut. Di lain pihak terjadi sinergi hasil blending 60\% berat OWC dan 40\% berat CT pada suhu perlakuan panas di atas $300^{\circ} \mathrm{C}$ yang menghasilkan kuat tekan sampel lebih tinggi dibandingkan kuat tekan sampel OWC atau CT saja. Tidak adanya portlandit dan adanya bahan pengisi dalam campuran tersebut diperkirakan menjadi sebab terjadinya peningkatan kuat tekan semen hasil blending.
\end{abstract}

Kata kunci: gasifikasi batubara bawah tanah, semen sumur minyak, castables, perlakuan panas 


\section{INTRODUCTION}

Indonesian coal production from open pit mining is estimated to reach its peak in 2026 and subsequently will decreases due to limited coal reserves (Rosyid and Adachi, 2016). Extraction of deeper coal seam should be considered if Indonesia remains depend on coal for its energy. Deep coal seam may be extracted using two methods, namely underground coal mining and underground coal gasification (UCG).

Underground coal mining has been one of the highest risk activities as far as the safeties of the workforces are concerned. The safety risks to coal miners include mine explosions, mine fires and falls of the mine roof (ILO, 2009). UCG is safer than underground mining since there is no worker underground however there is a concern for the UCG in ground water pollution. UCG convert coal insitu to combustible gas through some process including construction of injection and production well, ignition of coal and gasification process. The $R \& D$ Centre for Mineral and Coal Technology, Ministry of Energy and Mineral Resources is developing a UCG technology and has conducted a test in coal mines at Musi Banyuasin, South Sumatra. During the the target coal was ignited, the product gas was analyzed and the gasifier was shutdown successfully. The successful test will pave the way of UCG scale up into a commercial scale in Indonesia.

The gas comes out from the production well contains hydrogen, carbon monoxide (CO), carbon dioxide $\left(\mathrm{CO}_{2}\right)$, methane $\left(\mathrm{CH}_{4}\right)$ and impurities such as benzene and phenols. In order to prevent ground water pollutions, aquifer layers in the vicinity of UCG gasifier should be protected from contact with the impurities through a proper installation of well casing and cementing. Well cementing is the process of placing cement slurry in the annulus space between the well casing and the geological formations surrounding the well bore. When setting, the cement will establish a bond between the pipe and the formation.

Portland cement is the most commonly used cement in the oil and gas industry and it accounts for about $99 \%$ of all primary cementing operations throughout the world (Broni-Bediako, Joel and Ofori-Sarpong,
2015). For Portland cement to qualify as oil well cement, the chemical and physical properties must meet the required standards of the American Petroleum Institute (API). The American Petroleum Institute (API) classifies the oil well cement (OWC) into eight classes. Many additives have been proposed to improve the quality of Portland cement based on OWC. Addition of phosphogypsum (Hua, Wang and Yao, 2016) and meta-kaolin (Bu et al., 2016) decreases permeability of hardened OWC. Aluminum powder and nano meta-kaolin decrease the volume shrinkage, silica powder increases the strength and reduce the porosity (Costa et al., 2017; ElGamal, Hashem and Amin, 2017; Liu, Bu and Guo, 2013), $\mathrm{CaCL}_{2}$ or $\mathrm{NaCl}$ accelerates the hardening, bentonite decreases the slurry density and polypropylene glycol reduces the foam in the Portland a cement based the OWC (Broni-Bediako, Joel and OforiSarpong, 2016), mullite $\left(3 \mathrm{Al}_{2} \mathrm{O}_{3} \cdot 2 \mathrm{SiO}_{2}\right)$ (Han, Chen and $\mathrm{Li}, 2007$ ) and corundum (Chen et al., 2015) increase high-temperature strength. Limestone improves nucleation process (Hamdy and El-Sayed, 2000; De Schutter, 2011; Jeong et al., 2017) and gehlenite improves the mechanical properties of the OWC (Martin et al., 2005). Both OWC of API Class A or API Class G has also been used for cementing a geothermal well (Hole, 2008; Bett, 2010). However some properties modification is needed to withstand the acidic nature and high temperature condition of a geothermal well. It is found that graphite and meta kaolin addition into a Portland cement improve the thermal properties of such cement (Brandl and Doherty, 2013). Other type of cement, calcium aluminate and a calcium aluminate phosphate may also be used for well cementing. It is found that calcium aluminate and calcium aluminate phosphate cement is more resistant to acidic attack and high temperature environment (Sugama, 2007; Zivica et al., 2012).

Portland cement are designed to be used at temperature lower than that of $350^{\circ} \mathrm{C}$ and pressure lower than that of 200 Mpa (BroniBediako, Joel and Ofori-Sarpong; 2015), on the other hand, the UCG process involves temperature up to $1300^{\circ} \mathrm{C}$ (Blinderman and Klimenko, 2017). Therefore development of special cement for UCG is inevitable. The objective of this study is to modify the OWC properties so that it is capable to withstand at high temperature environment by blending it with calcium aluminate cement. Castables 
were selected as the source of calcium aluminate.

\section{EXPERIMENTS}

The materials used in this study are a class G oil well cements (OWC) and a castable (CT). The OWC brand name is Tiga Roda produced by PT. Indocement, Indonesia. The castable brand name is Jarefu produced by PT. Jaya Refractorindo Utama, Tangerang, Indonesia. In order to examine the impact of CT addition on the OWC properties, mixtures with different proportion of CT were prepared. Proportion of each cement and their notation in each mixed are presented in Table 1. The notations were based on the weight percentage of each cement in a sample. The notation for blended cement with proportion of $80 \%$ weight of OWC and $20 \%$ weight of CT was OWC80CT20. Each mix was reacted with the tap water forming paste and poured into a prepared mold. The ratio of cement to water is 4 to 6 (Lin and Meyer, 2009). After 24 hours, all samples were demolded, and then subjected to curing programs for 7 days. The mold was made from a PVC in a cylinder shape with diameter of $2.9 \mathrm{~cm}$ and height of $5,8 \mathrm{~cm}$. After curing, the hardened cement was inserted to a furnace and heated at different temperatures $(300,500$, 700 and $900^{\circ} \mathrm{C}$ ) for 2 hours at heating rate of $5^{\circ} \mathrm{C} / \mathrm{min}$. The code for blended $90 \%$ OWC and $10 \% \mathrm{CT}$ hardened $(\mathrm{H})$ with water and heat treated $(\mathrm{HT})$ at temperature of $300^{\circ} \mathrm{C}$ was OWC90CT10+H+HT300.

XRD analysis and uniaxial compressive strength (UCS) test were performed to investigate the impact of cement blend composition and heat treatment temperature on mineral compositions and strength of samples, respectively. Compressive strength test was conducted using an ELE universal compressive strength machine. The value of uniaxial compressive strength (UCS) was calculated by dividing the maximum load with cross sectional area. Figure 1 showed UCS test apparatus and its sample. ELE International is a company specializes in the design, manufacture, and supply of testing equipment and environmental instrumentation.

\section{RESULT AND DISCUSSIONS}

Raw materials used for the manufacture of cement consist mainly of limestone $\left(\mathrm{CaCO}_{3}\right)$, clay $\left(\mathrm{Al}_{2} \mathrm{O}_{3} \cdot \mathrm{SiO}_{2}\right)$, silica $\left(\mathrm{SiO}_{2}\right)$, alumina $\left(\mathrm{Al}_{2} \mathrm{O}_{3}\right)$ and iron oxide $\left.\mathrm{Fe}_{2} \mathrm{O}_{3}\right)$. These oxides interact in the kiln at high temperature to form silicate and aluminate minerals such as tricalcium silicate $\left(3 \mathrm{CaO} . \mathrm{SiO}_{2}\right)$, dicalcium silicate $\left(2 \mathrm{CaO} . \mathrm{SiO}_{2}\right)$, tricalcium aluminate $\left(3 \mathrm{CaO} . \mathrm{Al}_{2} \mathrm{O}_{3}\right)$ and tetracalcium aluminoferrite $\left(4 \mathrm{CaO} \cdot \mathrm{Al}_{2} \mathrm{O}_{3} \cdot \mathrm{Fe}_{2} \mathrm{O}_{3}\right)$. To make the formulas of cement minerals, shorter and easier to read, it is traditional to use a shorthand notation that leaves out the oxygen. The notations for $\mathrm{SiO}_{2}, \mathrm{CaO}$ and $3 \mathrm{CaO} . \mathrm{SiO}_{2}$ are $\mathrm{S}, \mathrm{C}$ and C3S, respectively.

Composition of cements is characterized by their oxide component and minerals. Table 2 shows the oxides component in Oil Well Cement (OWC100) and castable (CT100) and their notation. OWC contains high proportion of $\mathrm{CaO}(\mathrm{C})$ and $\mathrm{SiO}_{2}$ while CT contains high proportion of $\mathrm{Al}_{2} \mathrm{O}_{3}(\mathrm{~A})$. At high temperature, the above oxide may form calcium aluminate (CA) and/or calcium aluminum silicate. It seem that both cement do not contain gypsum $\left(\mathrm{CaSO}_{4}\right)$ since the $\mathrm{SO}_{3}$ content is very low. Gypsum usually is added to cement clinker to reduce the rate of cement hydration (hardening).

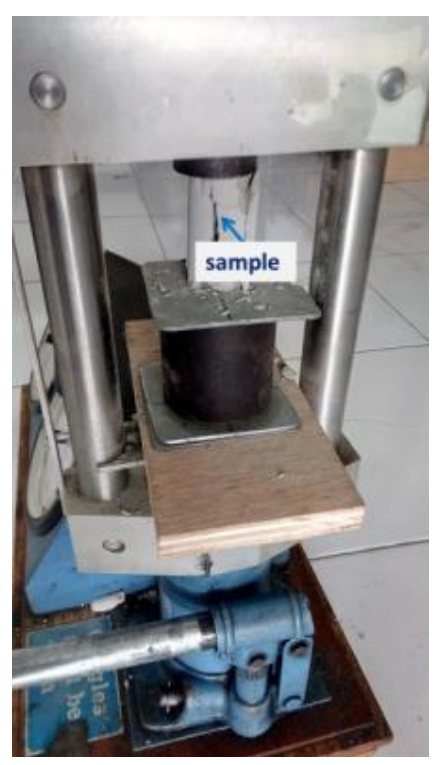

Figure 1. UCS test apparatus and its sample 
Table 1. Proportion of each cement for the study

\begin{tabular}{ccccccc}
\hline Code and units & OWC100 & OWC90CT10 & OWC80CT20 & OWC70CT30 & OWC60CT40 & CT100 \\
\hline OWC $(\%, w t)$ & 100 & 90 & 80 & 70 & 60 & 0 \\
CT $(\%, w t)$ & 0 & 10 & 20 & 30 & 40 & 100 \\
\hline
\end{tabular}

Table 2. Castable (CT) and Oil Well Cement (oxide) compositions

\begin{tabular}{ccccc}
\hline Compositions & Code & $\begin{array}{c}\text { OWC100 Powder } \\
(\%)\end{array}$ & $\begin{array}{c}\text { CT100 Powder } \\
(\%)\end{array}$ & Methods \\
\hline $\mathrm{SiO}_{2}$ & $\mathrm{~S}$ & 23.80 & 16.20 & AAS \\
$\mathrm{Al}_{2} \mathrm{O}_{3}$ & $\mathrm{~A}$ & 2.86 & 61.57 & AAS \\
$\mathrm{Fe}_{2} \mathrm{O}_{3}$ & $\mathrm{~F}$ & 4.73 & 1.76 & AAS \\
$\mathrm{K}_{2} \mathrm{O}$ & $\mathrm{K}$ & 0.63 & 0.51 & AAS \\
$\mathrm{Na}_{2} \mathrm{O}$ & $\mathrm{N}$ & 0.47 & 0.46 & AAS \\
$\mathrm{CaO}$ & $\mathrm{C}$ & 61.66 & 15.42 & AAS \\
$\mathrm{MgO}$ & $\mathrm{M}$ & 2.99 & 0.49 & AAS \\
$\mathrm{TiO}_{2}$ & $\mathrm{~T}$ & 1.03 & 2.89 & Spectrophotometry \\
$\mathrm{MnO}$ & $\mathrm{M}$ & 0.057 & 0,027 & AAS \\
$\mathrm{P}_{2} \mathrm{O}_{5}$ & $\mathrm{P}$ & 0.025 & 2.48 & Spectrophotometry \\
$\mathrm{LOI}^{\mathrm{SO}}$ & - & 1.95 & 0.81 & Gravimetry \\
$\mathrm{H}_{3} \mathrm{~S}$ & $\mathrm{~S}$ & $<0.001$ & $<0.001$ & Gravimetry \\
\hline
\end{tabular}

Figure 2 shows the types of minerals in the OWC and CT determined by the XRD instrument. Calcium silicate phases, belite/C2S and alite/C3S, dominated the minerals in OWC. Meanwhile CT contained many more minerals such as calcium aluminate, calcium aluminum silicate (CAS), mullite, gehlenite, corundum, and calcite (limestone). Based on their hydraulic minerals, cement can be classified as calcium silicate cement (Portland cement), calcium aluminate cement, sulphate cement, sulpho-aluminate cement and phosphate cement (Zhang, 2011). Hydraulic mineral is a kind of mineral when it is blended with water can generate the plastic paste which will turn into hard cement block. From the XRD result in Figure 2, it is concluded that both OWC and CT are classified as calcium silicate and calcium aluminate cement, respectively.



Figure 2. Diffractogram of oil well cement powder(OWC100) and castable (CT) powder Note: 1. $\mathrm{Ca}_{2} \mathrm{SiO}_{4}$ (C2S/Belite); 2. $\mathrm{Ca}_{3} \mathrm{SiO}_{5}$ (C3S/Alite); 3. $\mathrm{Ca}_{2} \mathrm{Al}_{2} \mathrm{SiO}_{7}$ (Gehlenite); 4. $\mathrm{CaAl}_{2} \mathrm{O}_{4}$ (CA); 5. $\mathrm{Al}_{2} \mathrm{O}_{3}$ (A/Corundum); 6. $\mathrm{Al}_{6} \mathrm{Si}_{2} \mathrm{O}_{13}$ (Mullite); 7. $\mathrm{CaCO}_{3}$ (Calcite) 
In the Ordinary Portland Cement (OPC), the proportion of $\mathrm{C} 3 \mathrm{~S}, \mathrm{C} 2 \mathrm{~S}, \mathrm{C} 3 \mathrm{~A}$ and $\mathrm{C} 3 \mathrm{AF}$ accounting for $37-60 \%, 15-37 \%, 7-15 \%$ and $10-18 \%$, respectively (Zhang, 2011). However, in the OWC (Figure 2), C3A and C3AF were not detected. It is may be due to less amount of alumina in the OWC (Table 1). Base on American Petroleum Institute (API) specification number $10 \mathrm{~A}$, the content of $\mathrm{C} 3 \mathrm{~A}$ in moderate sulfate resistance class $\mathrm{G}$ oil well cement must less than $8 \%$ and there is not description in minimum content of C3AF in the standard. Therefore this Indocement made the OWC met with the API standard.

OWC is a basic cement. It needs chemicals additive to change the performance of the cement to address the specific and unique conditions of each well. Typical chemical additives for cementing operations include; accelerators, retarders, extenders, fluid loss and loss circulation additives, dispersants, and many more. Shallow UCG wells may require accelerator to shorten the time for "Waiting-onCement (WOC)" before drilling operation can be resumed. Calcium chloride and sodium chloride are the most commonly used as accelerator. Other types of accelerators include sodium meta-silicate, potassium chloride and gypsum (Broni-Bediako, Joel and Ofori-Sarpong, 2016).

Castable is composed basically of two phases: a matrix phase containing hydraulic mineral plus fine refractory aggregates, and a dispersed phase consisting of coarse and medium refractory aggregates (Prata, Libardi and Baldo, 2003; ACl, 2013). As shown in Figure 2, hydraulic mineral in the $C T$ is calcium aluminate (CA) while gehlenite (CAS), mullite, corundum and calcite (limestone) are the aggregate. The function of fine aggregates improve particle packing efficiency by filling the gap between cement grain and coarse aggregates (Parr, Fryda and Wöhrmeyer, 2013). In addition, the aggregate in refractory castables is also resistant to the high temperature environment.

ASTM C401-91 classifies castable based on its $\mathrm{CaO}$ content into regular castable refractory $(\mathrm{CaO}>2.5 \%)$, low cement castable refractory $\quad(1 \%<\mathrm{CaO}<2.5 \%)$, ultra-low cement castable refractory $(0.2 \%<\mathrm{CaO}<1 \%)$ and no cement castable refractory $(\mathrm{CaO}<0.2 \%)$. Regular refractory castables are also called traditional or conventional castables and often contains $\mathrm{CaO}$ greater than 15\% (Parr et al., 1997). The Jarefu castable used in this study is classified as the regular castables.

Figure 3 shows the results of XRD analysis of OWC powder (OWC100), OWC hardened and heat treated at room temperature (OWC100+H+RT), OWC hardened and heat treated at $300^{\circ} \mathrm{C}$ (OWC100+ $\left.+\mathrm{H}+\mathrm{HT} 300 \mathrm{C}\right)$ and $\mathrm{OWC}$ hardened and heat treated at $500^{\circ} \mathrm{C}(\mathrm{OWC} 100+\mathrm{H}+\mathrm{HT} 500 \mathrm{C})$. The OWC powder (OWC100) showed only alite and belite peaks that decreased after the OWC was reacted with water and cured $(\mathrm{OWC} 100+\mathrm{H})$ moreover new phases namely portlandite appeared. The peaks intensity of portlandite showed maximum at heat treatment temperature of $300^{\circ} \mathrm{C}$ and then decrease at heat treatment temperature of $500^{\circ} \mathrm{C}$. The process of mixing cement with water and then curing treatment for 7 days at room temperature is called hardening process.

Intensity decrease of alite and belite peaks after hardening were caused by mineral dissolutions. When Portland cement is mixed with water, alite and belite dissolve in water and then precipitate to produce an amorphous calcium silicate hydrate $(\mathrm{CSH})$ and portlandite (Ridi, 2010; Skantz, 2014). The reactions of alite and belite with water are as follows:

$$
\begin{aligned}
& 2\left(3 \mathrm{CaO} \cdot \mathrm{SiO}_{2}\right)+6 \mathrm{H}_{2} \mathrm{O}=3 \mathrm{CaO} \cdot 2 \mathrm{SiO}_{2} \cdot 3 \mathrm{H}_{2} \mathrm{O} \\
& +3 \mathrm{Ca}(\mathrm{OH})_{2}, \\
& 2\left(2 \mathrm{CaO} \cdot \mathrm{SiO}_{2}\right)+4 \mathrm{H}_{2} \mathrm{O}=3 \mathrm{CaO} \cdot 2 \mathrm{SiO}_{2} \cdot 3 \mathrm{H}_{2} \mathrm{O} \\
& +\mathrm{Ca}(\mathrm{OH})_{2}
\end{aligned}
$$

Dissolution of alite and belite into amorphous calcium silicate hydrate reduces the intensity of belite and alite peaks in the difractogram (Figure 3). Alite reacts relatively rapid with water and is responsible for most of the early strength development of concretes. Belite is less reactive at early ages, but then can contribute appreciably to strength at later ages (Molèn, 2014).

The increase of portlandite XRD peaks (Figure 3) at temperature of $300^{\circ} \mathrm{C}$ means the heat treatment temperature up to $300^{\circ} \mathrm{C}$ promote portlandite formation through alite and belite hydration (Kang et al., 2017). Handoo, Agarwal and Agarwal (2002) examined morphology of portlandite by SEM and revealed that the morphology of portlandite after $200^{\circ} \mathrm{C}$ - heat treatment did 
not show any changes, but the portlandite crystals are deformed at $300^{\circ} \mathrm{C}$ and it was completely decomposed at $700^{\circ} \mathrm{C}$ (Handoo, Agarwal and Agarwal, 2002; Skantz, 2014). Portlandite decomposition is one of the reasons for decreasing peaks at $500^{\circ} \mathrm{C}$-heat treatment temperature.

Figure 4 shows the results of XRD analysis for CT cement powder (CT100), CT after hardening $(\mathrm{CT} 100+\mathrm{H})$, CT after hardening and heat treatment at $300^{\circ} \mathrm{C}$ (CT100+H+HT300C) and CT after hardening and heat treatment at $500^{\circ} \mathrm{C}$ (CT100+H+HT500C). In the difractogram, calcium aluminate peaks that showed as the greatest peaks before (CT100) hardening is disappeared after $(\mathrm{CT} 100+\mathrm{H})$ hardening and also after heat treatment. Calcium aluminate (CA) reacts with the water to form a series of calcium aluminate hydrates $(\mathrm{CAH})$. The lost of $\mathrm{CA}$ peaks in the XRD difractogram suggests that almost all the crystalline CA dissolve in water to form amorphous phase of $\mathrm{CAH}$.

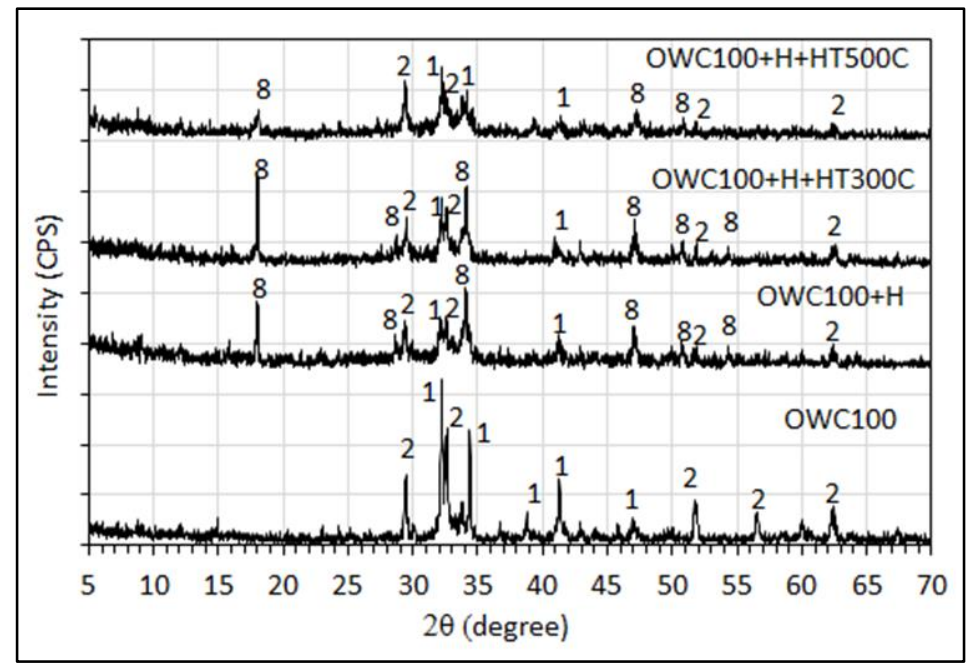

Figure 3. XRD pattern of OWC powder and OWC hardened and heat treated at several temperatures Note: 1. $\mathrm{Ca}_{2} \mathrm{SiO}_{4}\left(\mathrm{C} 2 \mathrm{~S} /\right.$ belite); 2. $\mathrm{Ca}_{3} \mathrm{SiO}_{5}$ (C3S/alite); 3. $\mathrm{Ca}_{2} \mathrm{Al}_{2} \mathrm{SiO}_{7}$ (gehlenite); 4. $\mathrm{CaAl}_{2} \mathrm{O}_{4}(\mathrm{CA})$;

5. $\mathrm{Al}_{2} \mathrm{O}_{3}$ (A/corundum); 6. $\mathrm{Al}_{6} \mathrm{Si}_{2} \mathrm{O}_{13}$ (mullite); 7. $\mathrm{CaCO}_{3}$ (calcite); 8. $\mathrm{Ca}(\mathrm{OH})_{2}$ (Portlandite)

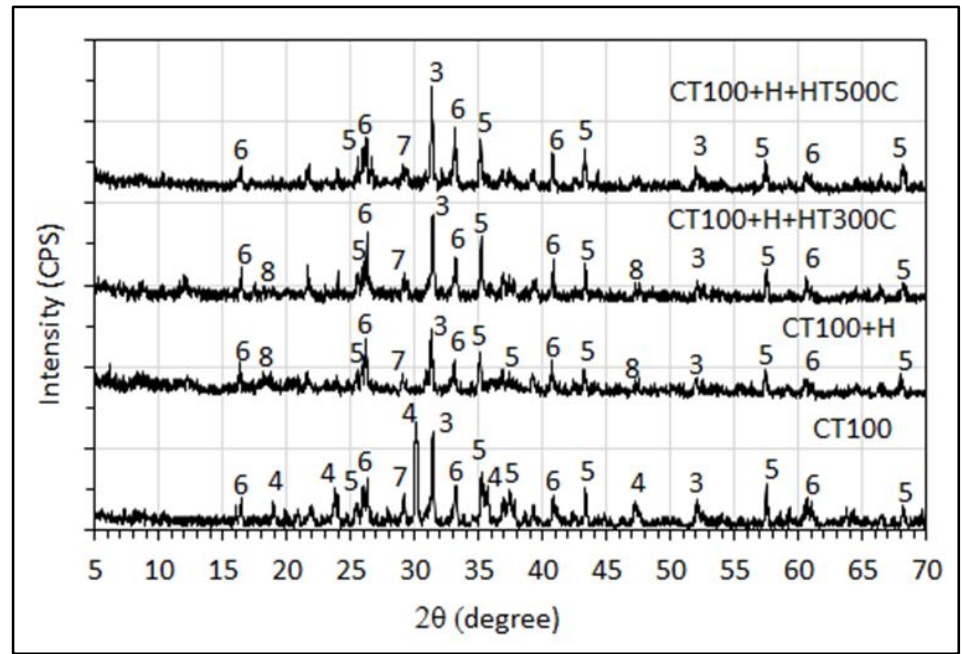

Figure 4. XRD pattern of CT powder and CT hardened and heat treated at several temperatures Note: 1. $\mathrm{Ca}_{2} \mathrm{SiO}_{4}$ (C2S/belite); 2. $\mathrm{Ca}_{3} \mathrm{SiO}_{5}$ (C3S/alite); 3. $\mathrm{Ca}_{2} \mathrm{Al}_{2} \mathrm{SiO}_{7}$ (gehlenite); 4. $\mathrm{CaAl}_{2} \mathrm{O}_{4}$ (CA); 5. $\mathrm{Al}_{2} \mathrm{O}_{3}$ (Corundum); 6. $\mathrm{Al}_{6} \mathrm{Si}_{2} \mathrm{O}_{13}$ (mullite); 7. $\mathrm{CaCO}_{3}$ (calcite); 8. $\mathrm{Ca}(\mathrm{OH})_{2}$ (Portlandite) 
Small peaks of Portlandite appear in XRD difractogram of CT after hardening process although hydration of CA does not form Portlandite. It may be formed by reaction of free $\mathrm{CaO}$ and water. Portlandite peaks intensity decrease with the increase of heat treatment temperature and diminished after the treatment at $500^{\circ} \mathrm{C}$ $\left(\mathrm{CT} 100+\mathrm{H}+\mathrm{HT} 500^{\circ} \mathrm{C}\right)$. On the contrary, gehlenite peaks intensity increases with the increase of heat treatment temperature. It is suggested that during treatment at temperature above $300^{\circ} \mathrm{C}$, the portlandite decomposes to produce the $\mathrm{CaO}$ and subsequently the $\mathrm{CaO}$ reacted with aluminum silicate to form gehlenite. Reaction of $\mathrm{CaO}$ with aluminum silicate is called as pozzolanic reaction. Higher temperature is effective in accelerating the pozzolanic reaction (Kang et al., 2017).

Mullite, corundum, gehlenite and calcite peaks appear in all XRD difractogram peaks (Figure 4). Therefore, the above materials act as inert filler that does not react with water and transform to other phase after the heat treatment. The peaks intensity increases of filler material after heat treatment are caused by sample dehydration. Both mullite and corundum are desirable in castable due to their excellent high-temperature strength and creep resistance, good chemical and thermal stability, low coefficient of thermal expansion as well as high thermal shock resistance (Han, Chen and Li, 2007). On the other hand, gehlenite and calcite is undesirable in calcium aluminate cement since its limit refractoriness of castables (Parr et al., 2004). Calcite turns into $\mathrm{CaO}$ at $800-900^{\circ} \mathrm{C}$, and expands with temperature. Shrinkage may also start due to the decomposition of $\mathrm{CaCO}_{3}$ into $\mathrm{CO}_{2}$ and $\mathrm{CaO}$ with volume changes causing destructions (Arioz, 2007).

Figure 5 shows the results of XRD analysis for blended OWC and CT after hardening and heat treatment at $500^{\circ} \mathrm{C}$. CT proportions in the blended samples are $0 ; 10 ; 20 ; 30$; $40 \%$. Portlandite peak was detected only in OWC100+H+HT500C suggesting addition of $\mathrm{CT}$ and heat treatment prevent its formation. $\mathrm{CA}$, a hydraulic component of CT was not detected while hydraulic components of OWC, Alite and belite peaks appeared in all blended sample in Figure 5. CA is very reactive to water and produces a amorphous phase as well as provide a rapid strength to harden the cement (Klaus, Neubauer and Goetz-Neunhoeffer, 2015).

The crystalline phases appeared in the blended of $60 \%$ weight OWC and $40 \%$ weight CT heat treated at $500^{\circ} \mathrm{C}$ (OWC60CT40+H+HT500C) were belite, alite (2), corundum (5), mullite (6) and calcite (7). Alite and belite were derived from hardened OWC and other phases were form hardened CT heat treated at $500^{\circ} \mathrm{C}$. Among the crystalline phases in the hardened CT only gehlenite was absent in the OWC60CT40+ $\mathrm{H}+\mathrm{HT} 500 \mathrm{C}$ sample.

According to Peng, Chan and Anson (2001) alite and belite are the main products of $\mathrm{CSH}$ decomposition at $600-800^{\circ} \mathrm{C}$ while CA were product of $\mathrm{CAH}$ decomposition at above $750^{\circ} \mathrm{C}$ (Maaroufi et al., 2015). Since mullite and corundum are relatively inert and calcite decomposes around $900^{\circ} \mathrm{C}$, the crystalline phase is likely to appear at 600$900^{\circ} \mathrm{C}$ are alite, belite, calcium aluminate (CA), corundum, mullite and calcite. Detail study should be conducted to understand reactions among cement components at high temperature including to find a reason regarding the absence of gehlenite peaks in the blended OWC and CT.

Effect of heat temperature on the compressive strength of hardened cement is shown in Figure 6. All samples show almost the same compressive strength after heating at $300^{\circ} \mathrm{C}$. However, above $300^{\circ} \mathrm{C}$ the compressive strength of $\mathrm{OWC100}+\mathrm{H}$ reduced drastically while $\mathrm{CT} 100+\mathrm{H}$ maintained their compressive strength above 2 Mpa. According to Khoury (Handoo, Agarwal and Agarwal, 2002) the heat treatment below $300^{\circ} \mathrm{C}$ accelerate hydration that forms additional $\mathrm{CSH}$ to yield increasing compressive strength and further increase of heat treatment temperature reduces strength due to decomposition of $\mathrm{CSH}$ and portlandite (Arioz, 2007). 
INDONESIAN MINING JOURNAL Vol. 21, No. 2, October $2018: 77$ - 88

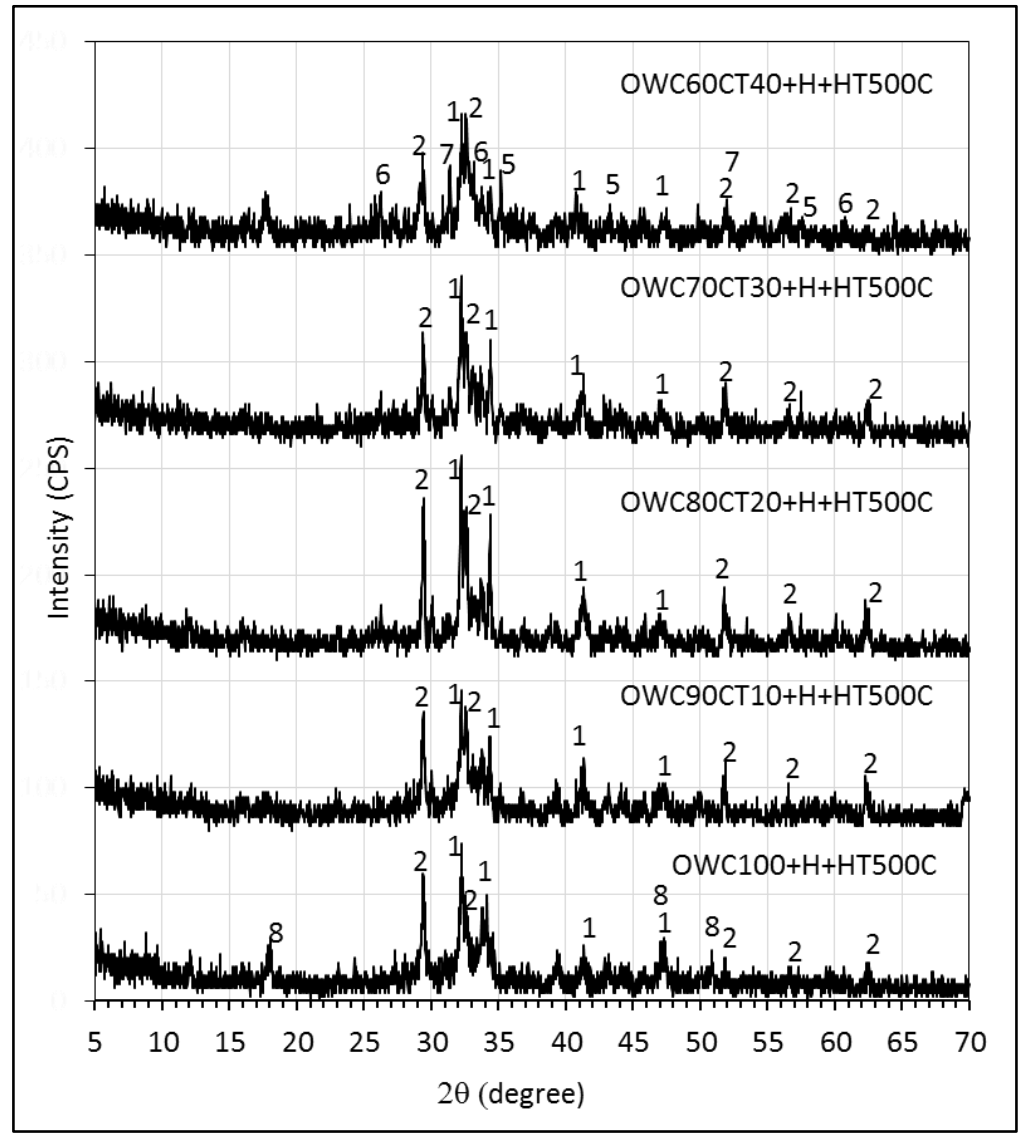

Figure 5. XRD pattern of blended OWC and CT with compositions of OWC $100 \%, 90 \%, 80 \% 70 \%$, and $60 \%$ hardened and then heat treated at $500^{\circ} \mathrm{C}$

Note: 1. $\mathrm{Ca}_{2} \mathrm{SiO}_{4}$ (C2S/belite); 2. $\mathrm{Ca}_{3} \mathrm{SiO}_{5}$ (C3S/alite); 3. $\mathrm{Ca}_{2} \mathrm{Al}_{2} \mathrm{SiO}_{7}$ (gehlenite); 4. $\mathrm{CaAl}_{2} \mathrm{O}_{4}(\mathrm{CA})$; 5. $\mathrm{Al}_{2} \mathrm{O}_{3}$ (Corundum); 6. $\mathrm{Al}_{6} \mathrm{Si}_{2} \mathrm{O}_{13}$ (mullite); 7. $\mathrm{CaCO}_{3}$ (calcite); 8. $\mathrm{Ca}(\mathrm{OH})_{2}$ (Portlandite)

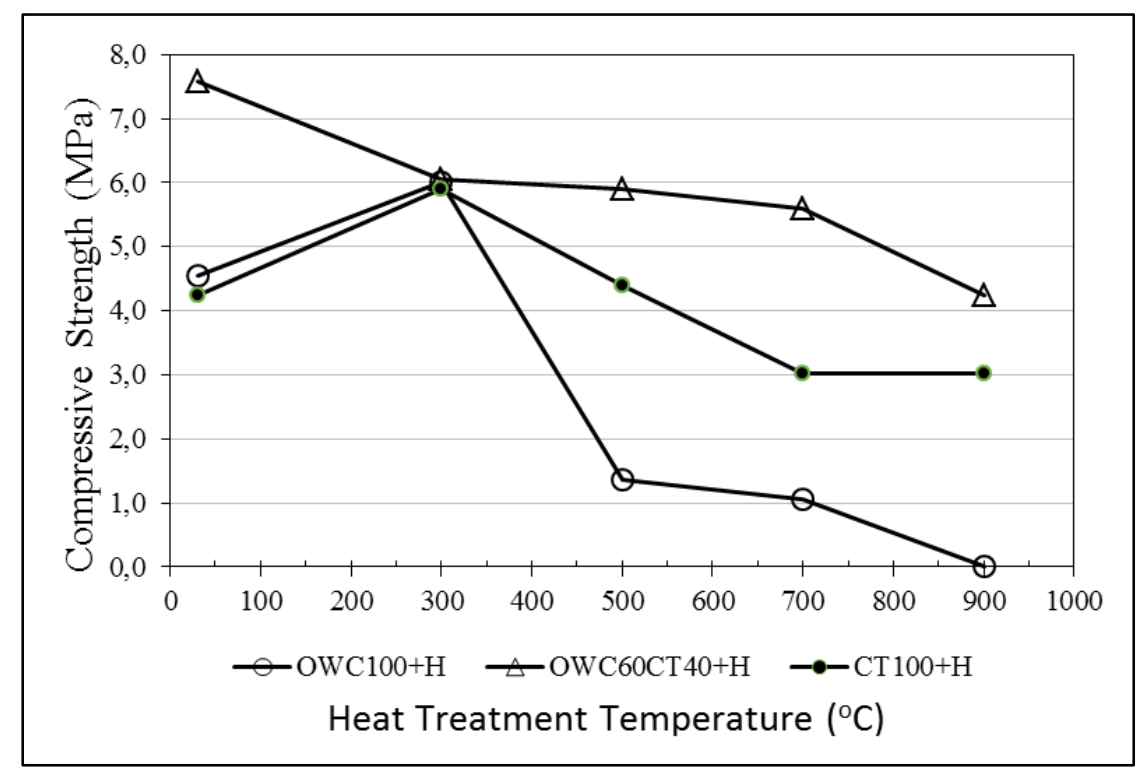

Figure 6. Effect of temperature on compressive strength of hardened cement 
There is a synergy effect if OWC and CT was blended. OWC60CT40+H showed highest compressive strength after curing at room temperature and after heat treated above $300^{\circ} \mathrm{C}$. The effect may be caused by the presence of filler mineral and the absence of portlandite in the blending. Based on XRD analysis, the OWC only contained hydraulic mineral (alite and belite) meanwhile CT addition to hydraulic mineral (calcium aluminate) contained a filler mineral such as gehlenite, corundum, mullite and calcite (Figure 2). The filler mineral in CT reduced the porosity of blended OWC-CT. According to Parr, Fryda and Wöhrmeyer (2013), filler minerals optimized particle packing in the hardened Portland cement, decreased porosity and increased the mechanical strength.

Portlandite is known as a mineral that can deteriorate hardened cement at high temperature. Above $300^{\circ} \mathrm{C}$ chemically bound water in the portlandite begins to evolve and then creates micro cracks in hardened cement which reduces strength (Arioz, 2007). Due to the above dehydration reaction, reduction in $\mathrm{Ca}(\mathrm{OH})_{2}$ content within the hardened cement along with the temperature increase is used to indicate deterioration in concrete quality (Handoo, Agarwal and Agarwal, 2002). Since the Portlandite peak was absence in the OWCCT (Figure 5) blend the samples at high tempertaure (above $300^{\circ} \mathrm{C}$ ) yielded a higher strength of material.

As the UCG process is conducted at temperature up to $1300^{\circ} \mathrm{C}$ (Blinderman and Klimenko, 2017), choosing cementing material is indispensable. The pure oil well cement (Portland cement) is not suitable for annulus cementing of the UCG wells since its compressive strength reduced drastically at above $300^{\circ} \mathrm{C}$. The blended OWC and CT may be used for cementing the UCG well since it is resistant to a high temperature environment (Figure 6). Since the calcium aluminate harden very fast (Klaus, Neubauer and Goetz-Neunhoeffer, 2015), the use of accelerator type additive in the cement slurry may not be needed. The high-alumina content in the blend may increase also its resistant to acidic attack (Zivica et al., 2012). Nonetheless, the castable (calcium aluminate cement) is more expensive than that of the Portland cement (Bizzozero, 2014). The use of blended OWC-CT only at the bottom of well that is exposed to a high temperature is recommended to reduce the cost of cement. In the top side of the well, the water may be injected to decrease gas temperature below $300^{\circ} \mathrm{C}$ for protecting the hardened OWC cement and valves in the well head.

\section{CONCLUSIONS}

The development of cement for cementing the UCG well has been conducted by blending the Indonesia oil well cement and a castable. The conclusion is as follows:

1. Tiga Roda, the brand of Oil Well Cement (OWC) is classified as a Portland cement since it contains calcium silicate (alite and belite) as hydraulic minerals.

2. Jarefu, a brand of castable (CT) cement contains calcium aluminate as a hydraulic mineral and filler material. The CT is classified as calcium aluminate cement.

3. Hydration of the OWC produces unreacted alite, unreacted belite and portlandite as well.

4. Unreacted calcium aluminate was not detected after CT hydration process

5. OWC compressive strength at heat treatment above $300^{\circ} \mathrm{C}$ reduced drastically due to decomposition of portlandite and calcium silicate hydrate.

6. There is a synergy effect if $60 \%$ of OWC weight and $40 \%$ of CT weight were blended. The absence of portlandite and the presence of inert filler in the blend improve the property of the blend at high temperature.

\section{ACKNOWLEDGEMENTS}

The author gratefully acknowledges the R\&D Centre for Mineral and Coal Technology of the Republic of Indonesia for its financial support and thanks also to Mrs. lis Hayati for helping this research. 


\section{REFERENCES}

ACl (2013) ACl concrete terminology. Farmington Hills: American Concrete Institute. Available at:

https://www.concrete.org/portals/0/files/p $\mathrm{df} / \mathrm{ACl} \mathrm{Cl}$ Concrete_Terminology.pdf.

Arioz, O. (2007) "Effects of elevated temperatures on properties of concrete," Fire Safety Journal, 42(8), pp. 516-522. doi: 10.1016/j.firesaf.2007.01.003.

Bett, E. K. (2010) Geothermal well cementing, materials and placement techniques. Reykjavík, Iceland. Available at: https://orkustofnun.is/gogn/unu-gtpreport/UNU-GTP-2010-10.pdf.

Bizzozero, J. (2014) Hydration and dimensional stability of calcium aluminate cement based systems. École Polytechnique Fédérale de Lausanne. doi: 10.5075/epfl-thesis-6336.

Blinderman, M. and Klimenko, A. (eds.) (2017) Underground coal gasification and combustion. Duxford, UK: Woodhead Publishing.

Brandl, A. and Doherty, D. R. (2013) "Method of producing synthesis gas by the underground gasification of coal from a coal seam." United State of America. Available at:

https://patents.google.com/patent/US85 96356

Broni-Bediako, E., Joel, O. F. and Ofori-Sarpong, G. (2015) "Evaluation of the performance of local cements with imported class ' $G$ ' cement for oil well cementing operations in Ghana," Ghana Mining Journal, 15(1), pp. 78-84. Available at:

https://www.ajol.info/index.php/gm/articl e/view/119503.

Broni-Bediako, E., Joel, O. F. and Ofori-Sarpong, G. (2016) "Oil Well Cement Additives: A Review of the Common Types," Oil \& Gas Research, 02(02), pp. 1-6. doi: $10.4172 / 2472-0518.1000112$.

$\mathrm{Bu}$, Y., Du, J., Guo, S., Liu, H. and Huang, C. (2016) "Properties of oil well cement with high dosage of metakaolin," Construction and Building Materials, 112, pp. 39-48. doi: 10.1016/j.conbuildmat.2016.02.173.

Chen, H., Zhao, L., He, X., Fang, W., Lei, Z. and Chen, H. (2015) "The fabrication of porous corundum spheres with core-shell structure for corundum-spinel castables," Materials \& Design, 85, pp. 574-581. doi: 10.1016/j.matdes.2015.07.033.

Costa, B. L. de S., Souza, G. G. de, Freitas, J. C. de O., Araujo, R. G. da S. and Santos, P. H. S. (2017) "Silica content influence on cement compressive strength in wells subjected to steam injection," Journal of Petroleum Science and Engineering, 158, pp. 626-633. doi: 10.1016/j.petrol.2017.09.006.

El-Gamal, S. M. A., Hashem, F. S. and Amin, M. S. (2017) "Influence of carbon nanotubes, nanosilica and nanometakaolin on some morphologicalmechanical properties of oil well cement pastes subjected to elevated water curing temperature and regular room air curing temperature," Construction and Building Materials, 146, pp. 531-546. doi: 10.1016/j.conbuildmat.2017.04.124.

Hamdy, E.-D. and El-Sayed, E.-A. (2000) "Addition of limestone in the low heat portland cement," Ceramics - Silikáty, 44(4), pp. 146-150. Available at: http://www.ceramics-

silikaty.cz/index.php?page=cs_detail_doi \&id $=744$

Han, B., Chen, F. and Li, N. (2007) "Mullite castables bonded by calcium aluminate cement," American Ceramic Society Bulletin, 86(3), pp. 9301-9306. Available at:

http://americanceramicsociety.org/bulleti n/2007_pdf_files/Han.pdf.

Handoo, S. K., Agarwal, S. and Agarwal, S. K. (2002) "Physicochemical, mineralogical, and morphological characteristics of concrete exposed to elevated temperatures," Cement and Concrete Research, 32(7), pp. 1009-1018. doi: 10.1016/S0008-8846(01)00736-0.

Hole, H. (2008) "Geothermal well cementing," in Petroleum Engineering Summer School. Dubrovnik, Croatia, pp. 1-6. Available at:

https://pangea.stanford.edu/ERE/pdf/IG Astandard/ISS/2008Croatia/Hole06.pdf.

Hua, S., Wang, K. and Yao, X. (2016) "Developing high performance phosphogypsum-based cementitious materials for oil-well cementing through a step-by-step optimization method," Cement and Concrete Composites, 72, pp. 299-308. doi: 10.1016/j.cemconcomp.2016.05.017. 
ILO (2009) Safety and health in underground coalmines. 1st Ed. Geneva, Switzerland: International Labour Office. Available at: https://www.ilo.org/wcmsp5/groups/publi c/---ed_protect/---protrav/--safework/documents/normativeinstrume nt/wcms_110254.pdf

Jeong, Y., Hargis, C., Chun, S. and Moon, J. (2017) "Effect of calcium carbonate fineness on calcium sulfoaluminatebelite cement," Materials, 10(8), p. 900. doi: 10.3390/ma10080900.

Kang, S.-H., Lee, J.-H., Hong, S.-G. and Moon, J. (2017) "Microstructural investigation of heat-treated ultra-high performance concrete for optimum production," Materials, 10(9), p. 1106. doi: 10.3390/ma10091106.

Klaus, S. R., Neubauer, J. and Goetz-Neunhoeffer, F. (2015) "How to increase the hydration degree of $\mathrm{CA}$ - The influence of $\mathrm{CA}$ particle fineness," Cement and Concrete Research, 67, pp. 11-20. doi: 10.1016/j.cemconres.2014.08.001.

Lin, F. and Meyer, C. (2009) "Hydration kinetics modeling of Portland cement considering the effects of curing temperature and applied pressure," Cement and Concrete Research, 39(4), pp. 255-265. doi: 10.1016/j.cemconres.2009.01.014.

Liu, H., Bu, Y. and Guo, S. (2013) "Improvement of aluminium powder application measure based on influence of gas hole on strength properties of oil well cement," Construction and Building Materials, 47, pp. 480-488.

doi: 10.1016/j.conbuildmat.2013.05.057.

Maaroufi, M.-A., Lecomte, A., Diliberto, C., Francy, O. and Le Brun, P. (2015) "Thermohydrous behavior of hardened cement paste based on calcium aluminate cement," Journal of the European Ceramic Society, 35(5), pp. 1637-1646. doi: 10.1016/j.jeurceramsoc.2014.11.029.

Martin, P., Ján, M., Ján, M., Jana, K. and Chandra, M. S. (2005) "Formation and stability of crystallohydrates in the nonequilibrium system during hydration of SAB cements," Ceramics - Silikáty, 49(4), pp. 230-236. Available at: http://www.ceramics-

silikaty.cz/index.php?page $=c s \_d e t a i l \_d o i$ \&id=609.

Molèn, M. (2014) Early hydration of portland cement compounds: Synthesis and hydration of alite and calcium aluminate.
Chalmers Tekniska Högskola. Available at:

http://publications.lib.chalmers.se/record s/fulltext/202343/202343.pdf.

Parr, C., Bier, T. A., Bunt, N. E. and Spreafico, E. (1997) "Calcium aluminate cement (CAC) based castables for demanding applications," in Proceeding 1st monolithics conference. Tehran, Iran.

Parr, C., Fryda, H. and Wöhrmeyer, C. (2013) "Recent advances in refractories aluminate binders and calcium aluminate bonded high-performance monolithic castables," Journal of the Southern African Institute of Mining and Metallurgy, 113, pp. 619-629. Available at:

http://www.scielo.org.za/scielo.php?scrip $\mathrm{t}=\mathrm{sci}$ abstract $\&$ pid $=\mathrm{S} 2225$ 62532013000800007

Parr, C., Simonin, F., Touzo, B., Wöhrmeyer, C., Valdelievre, B. and Namba, A. (2004) "Chris Parr Simonin, F. Touzo, B. Wohrmeyer, C. Valdelievre, B. Namba, A.," in Proceeding TARJ meeting. Ako, Japan.

Peng, G. F., Chan, S. Y. N. and Anson, M. (2001) "Chemical kinetics of C-S-H decomposition in hardened cement paste subjected to elevated temperatures up to $800^{\circ} \mathrm{C}$," Advances in Cement Research, 13(2), pp. 47-52. doi: 10.1680/adcr.2001.13.2.47.

Prata, L. B., Libardi, W. and Baldo, J. B. (2003) "The effect of aggregate aspect ratio and temperature on the fracture toughness of a low cement refractory concrete," Materials Research, 6(4), pp. 545-550. doi: $10.1590 /$ S151614392003000400021.

Ridi, F. (2010) "Hydration of cement: Still a lot to be understood," La Chimica \& L'Industria, 3, pp. 110-117. Available at: http://www.soc.chim.it/sites/default/files/ chimind/pdf/2010 3 110 ca.pdf.

Rosyid, F. A. and Adachi, T. (2016) "Forecasting on Indonesian coal production and future extraction cost: A tool for formulating policy on coal marketing," Natural Resources, 07(12), pp. 677696. doi: $10.4236 / \mathrm{nr} .2016 .712054$.

De Schutter, G. (2011) "Effect of limestone filler as mineral addition in self-compacting concrete," in Tam, C. T., Ong, K. C. G., Teng, S., and Zhang, M. H. (eds.) 36th Conference on OUR World in Concrete 
INDONESIAN MINING JOURNAL Vol. 21, No. 2, October $2018: 77$ - 88

\& Structures: "Recent Advances in the Technology of Fesh Concrete." Singapore: Ghent University, Department of Structural engineering, pp. 49-54.

Skantz, E. (2014) Effect of elevated temperature on cement paste ageing. Aalto University. Available at:

https://www.semanticscholar.org/paper/

Effect-of-elevated-temperature-oncement-paste-

Skantz/76fa6b9f799b505b715244139de $6 \mathrm{c} 2 \mathrm{c} 8 \mathrm{df} 6 \mathrm{dce} 91$.
Sugama, T. (2007) Advanced cements for geothermal wells. Upton, NY. doi: 10.2172/909955.

Zhang, H. (ed.) (2011) Building materials in civil engineering. 1st Ed. Woodhead Publishing.

Zivica, V., Palou, M. T., Krizma, M. and Bagel, L. (2012) "Acidic attack of cement based materials under the common action of high, ambient temperature and pressure," Construction and Building Materials, 36, pp. 623-629. doi: 10.1016/j.conbuildmat.2012.04.025. 